\title{
Varmus nominated to head NIH
}

Washington. Microbiologist Harold Varmus of the University of California, San Francisco (UCSF), was last week officially nominated by President Bill Clinton as the next director of the US National Institutes of Health (NIH).

If confirmed, as expected, by the Senate in October, Varmus will take over from Bernadine Healy as director of the world's largest biomedical research institution. The Clinton administration asked Healy, a nominee of former President George Bush, to step down at the end of June.

Varmus won

\section{Harold Varmus} the Nobel prize for medicine in 1989 for his work with his colleague $\mathbf{J}$. Michael Bishop on the replication of retroviruses, and has spent most of his academic life at UCSF. He declined to discuss his plans for NIH before the confirmation hearings.

He said, however, that he was pleased with "the lack of politics" involved in the nomination process. Under the Reagan and Bush administrations, public opposition to abortion and fetal tissue research had been a prerequisite for the NIH post. This time, says Varmus, there were no litmus tests: "At no time was I asked my positions on any of the issues that have been controversial in the past".

Varmus will oversee the NIH's annual budget of more than US\$10 billion. He has no experience as an administrator. But his reputation as one of the world's leading scientists and as a champion of basic research appears to have won him the support of Donna Shalala, the Secretary of Health and Human Services, John Gibbons, the White House Science Advisor, and many prominent scientists.

"Because of my background, I have a feel for the issues that scientists both inside and outside the NIH are worried about," Varmus says. "That kind of perspective is needed in the policy arena."

The son of a general practitioner, Varmus graduated in English at Amherst College and subsequently studied seventeenth century literature at Harvard University. $\mathrm{He}$ later attended Columbia University Medical School where he earned an MD, but became sidetracked by an interest in experimental molecular biology.

Since graduating from Columbia in 1966, Varmus has been on the academic staff of UCSF, where he holds appointments in both the department of microbiology and immunology and the department of biochemistry and biophysics.

The Nobel prize that he shared with Bishop was awarded for their discovery of cellular oncogenes, segments of genetic material that can cause cancer when activated by viruses, chemicals and other environmental sources. The work has since laid the groundwork for the genetics of cancer, and has led to improved methods for diagnosis and for predicting who is at risk.

Despite Varmus's inexperience as an administrator, he is no stranger to Washington. For many years, he has lobbied Congress to protect basic research from political constraints. Earlier this year, he joined several prominent US scientists in urging the Clinton administration not to sacrifice fundamental research in its quest for a clearer definition of the nation's scientific and technological goals.

Three UCSF alumni will now occupy top US science policy positions. On 2 July, Philip R. Lee, former chancellor of the university and director of its Institute for Health Policy Studies, took office as assistant secretary of health. As such, he will be responsible for overseeing the NIH, the Department of Public Health Services and the Centers for Disease Control and Prevention.

In the same week, Bruce Alberts, another member of UCSF's department of biochemistry and biophysics, took office as president of the National Academy of Sciences. Alberts was chairman of the search committee that recommended Varmus for the NIH post.

Susan Greene

\section{Supercollider contract split in move to appease Senate}

Washington. Hazel O'Leary, the US Secretary of Energy, has decided to split the contract to build the Superconducting Super Collider (SSC) into separate construction and science components. As a result, the Universities Research Association (URA), which has until now held the contract for both aspects of the $\$ 8$-billion project, will be stripped of responsibility for its construction phase.

But O'Leary has rejected the findings of a report from the General Accounting Office (GAO) which claimed overspending on the SSC, reversing her position for the second time this year. She told a Senate committee last week that the project was "on schedule and on budget".

Asked why millions of dollars are to be spent reformulating a contract that appears to be going well, O'Leary said that the project "had not been well managed" by URA, and in particular that its costing systems were insufficiently transparent. "We should have been able to understand if the project was on time and on budget in a few days," she said. "Instead, it took us three or four weeks. We need to have the right systems and procedures in place."

But many observers in Washington see the plan to replace URA as a political ma- noeuvre designed to maximize Senate support for the SSC when it considers the matter next month by appearing to respond to the concerns raised by the GAO. In the light of O'Leary's action, such support now seems virtually assured, leaving the SSC's fate to be settled in a conference between the House of Representatives and the Senate.

Joe Barton (Republican, Texas), the representative in whose district the SSC is being built, expressed confidence after O'Leary's testimony last week that the House would "accept the Senate position". But the likely outcome of the conference remains uncertain.

Divisions within the administration surfaced during a hearing on the project before the Senate's sympathetic Energy and Natural Resources Committee, chaired by Senator Bennett Johnston (Democrat, Louisiana). Dr John Gibbons, the White House science adviser, voiced his irritation at a leaked memorandum criticizing URA from Joseph Cipriano, a senior energy department official. "I'm worried that $\mathrm{Mr}$ Cipriano feels that whenever we have a problem we find a scapegoat and throw him down the hill", said Gibbons. "I'm not sure how much large project management experience Mr Cipriano has."
At the same hearing, Steven Weinberg, the theoretical physicist, mounted a strong counterattack on the SSC's critics. Weinberg said he had read both the GAO report and an attack on it by the energy department's inspector general, and that "almost all of the complaints have been about accounting systems and audit systems, not about the building of the collider". URA, he said, had done a good job of the building work, even if it had not left a paper trail "that would satisfy every accountant"

O'Leary's decision came after a month long review of URA's management of the project by the Department of Energy. URA is a nonprofit-making body run by a consortium of universities which has managed the SSC for a fee of around 0.2 per cent of project costs, delegating the construction work to subcontractors.

O'Leary said that URA would retain control of the "science" side of the project. The department says that URA will still manage the collider's operations on completion, and that its role will therefore expand as completion approached. A senior energy department official was, however, unable to specify any important subcontract that would stay under URA's jurisdiction.

Colin Macilwain 